\title{
Az osteoporosis jeleinek reprodukálhatósága panoráma röntgenfelvételeken
}

\author{
DR. FEHÉR MÓNIKA*, DR. KUKI ATTILA**, DR. MOHÁCSI RITA***, \\ DR. BIRINYI LÁSZLÓ ${ }^{* \star *}$, DR. ANGYAL JÁNOS ${ }^{\star * \star}$
}

\begin{abstract}
Az osteoporosis krónikus degeneratív betegség, amely főleg a postmenopausa időszakában lévő nőket érinti. Szakirodalmi adatok szerint a panoráma felvételeken meghatározható morfometriai és vizuális indexek eredményesen alkalmazhatók a betegség korai felismerésében. Klinikai vizsgálatunk célja panoráma röntgenfelvételeken elemezni a mandibula corticalis és panoráma felvételi osteoporosis-indexeinek kísérletes reprodukálhatóságát. A vizsgálatban 40 fogorvostan-hallgató és két egyetemi oktató vett részt, akik 50 osteoporosisos (átlagéletkor $65,1 \pm 5,9$ év) és 36 (66,4 4 7,1 év) kontroll női páciens röntgenfelvételét elemezték azonos körülmények között. Az adatokat SPSS szoftver alkalmazásával értékeltük ki. A röntgenelemzést végzők között a corticalis index eredményeiben találtunk szignifikáns eltérést, más vonatkozásban az indexek reprodukálhatónak bizonyultak. A panoráma felvételeket meghatározott fogorvosi indikációval készítik, de amennyiben a fogorvos felismeri azokon az osteoporosis jeleit, a beteget szakrendelésre utalhatja, ahol megfelelő ellátásban részesíthetik.
\end{abstract}

Kulcsszavak: osteoporosis, orthopantomogram, mandibula corticalis index, panoráma index, reprodukálhatóság

\section{Bevezetés}

Az osteoporosis egy krónikus generalizált degeneratív népbetegség, amely főleg a nőket érinti a postmenopausa időszakában. Csak Európában mintegy 75 millió embert érint a kórkép [36]. A csontlebontás és felépítés között megbomlik az egyensúly, a csont állománya arányosan csökken, ami kezelés nélkül a csontminöség romlásához és fokozott törékenységhez vezet. Kialakulását a kor előrehaladtával a védő ösztrogénszint lecsökkenésén kívül befolyásolhatják még genetikai tényezők, alkoholfogyasztási szokások, dohányzás, nem megfelelő diéta, sovány testalkat és mozgásszegény életmód. Korai stádiumban sajnos nehezen ismerhető fel, mert a beteg panaszmentes. Mivel szisztémás betegségről van szó, minden csont érintett, de leggyakrabban a csigolyák, a combnyak és a csuklócsontok fraktúrája vezet a diagnózis felállításához [20]. A nők posztmenopauzás csontritkulása a trabecularis szerkezet felritkulásával kezdődik (ekkor jellemző a csigolyatestek és a radius distalis törése is), melyhez később, lassúbb ütemú leépülést eredményezve, a corticalis csont vesztése társul. Ez utóbbi eredménye a corticalis réteg radiológiai elvékonyodása, ami a mandibula panoráma felvételén is detektálható elváltozáshoz vezethet [14].
A fogorvosi szakirodalom régóta foglalkozik a mandibulán észlelhető radiológiai elváltozások és az osteoporosis kapcsolatával. Groen és mtsai már az 1960-as években összefüggést találtak a parodontális betegségek miatt kialakult fogvesztés, valamint az alkar és a csigolyák ásványi anyagtartalma között [10]. Az állkapocs az alkarcsontokhoz hasonlóan $80 \%$ corticalis és $20 \%$ trabecularis csontállományból épül fel [25], ami arra enged következtetni, hogy osteoporosisban célszerủ lehet a mandibula vizsgálata. A trabecularis csontszerkezet elemzése a kezdeti ígéretes adatok ellenére [35] nem vezetett jelentős eredményre, ugyanakkor a corticalis réteg elvékonyodásának és szerkezeti átalakulásának kutatása sikeres iránynak bizonyult [7]. Ennek egyik fő oka, hogy az alsó corticalis réteg redukciója a mandibulában gyorsabban zajlik, mint más csontok esetében, és értéke évenkénti 2,06\%-os csökkenésnek felel meg [8].

Az utóbbi évek kutatásai alapján összefüggés állapítható meg a mandibula ásványianyag tartalma, szerkezeti tulajdonságai, a processus alveolaris reszorpciója, valamint a test egyéb csontjainak ásványianyag tartalma között [22]. Ennek az összefüggésnek a megítélését azonban nehezíti, hogy az okklúziós erőhatások egyaránt befolyásolják az állcsont funkcióját és metabolizmusát, és a funkcióban bekövetkező változások is vezethetnek az ásványianyag-tartalom csökkenéséhez. 
Benson és mtsai szoros összefüggést fedeztek fel a mandibula panoráma felvételi indexe (PMI, a mandibula alsó corticalis lemezének szélességét tükröző arányszám) és a csigolyák denzitásértékei között [5], ami jelentős hatással volt a későbbi vizsgálatokra. Ezt követően került bevezetésre a mandibula corticalis indexe (MCl), de a szakirodalomban gyakran használják a mentalis indexet (MI) is, ami a PMI-nek megfelelő mutató és a mandibula alsó corticalis lemezének a szélessége cm-ben kifejezve [16]. Mivel a foramen mandibulae kívülesik a nagy rágóizmok tapadási területén, ezért ez az általánosan elfogadott régió a panoráma felvételi index és a mentalis index mérésére. $\mathrm{Az} \mathrm{MCl}$-t első leírói alapján Klemetti-indexnek is nevezik [16], az index pedig a mandibula radiopak corticalis lemezének integritását jellemzi.

Taguchi és mtsai szerint a mandibula corticalisának a vastagsága, a corticalis integritása, a meglévő fogak száma és a fogmedernyúlvány reszorpciója is utalhat látens csontritkulás jelenlétére, gyakran még az osteoporotikus törések bekövetkezte előtt [33]. Dutra és mtsai azt találták, hogy osteoporosisban a mandibula morfológiai változásokon megy keresztül, ami megmutatkozik a panoráma felvételen mérhető szögértékeken is [9]. Klemetti és mtsai szerint a mandibula panoráma felvételi indexének értékét regionális és etnikai tényezők is befolyásolhatják [15]. Nakamoto és mtsai pedig azt hangsúlyozzák, hogy a nagyobb szakmai gyakorlattal rendelkező fogorvosok pontosabban azonosítják az osteoporosis jeleit panoráma felvételeken [24].

Egyes szerzők arra mutatnak rá, hogy a panoráma felvételek költséghatékony diagnosztikus eszközök az osteoporosis által veszélyeztetett csoportok vizsgálatában [32, 27], kiemelve, hogy megfelelő alkalmazás esetén irreálisan nagy tehertől is megkímélhetnék a csontdenzitometriára épülő másodlagos prevenciós szolgálatokat. Hazánkban kb. 3,7 millió fő (nagyrészt nők) alkotja a rizikócsoportot, WHO kritériumok alapján pedig kb. 550 ezer főnél valószínűsíthető osteoporosis [31]. Nemzetközi ajánlásokkal összhangban, a családorvosi gyakorlatban a 65 év feletti, menopauza utáni nők, a 65 év alatti, fokozott kockázatnak kitettek, a rizikócsoportba tartozó nők és férfiak, illetve a típusos osteoporosisos törésen átesett páciensek szűrővizsgálatra utalását tartják indokoltnak. A hazai fogorvosi szakirodalomban Koppány és mtsai tekintették át az állcsontok denzitometriai vizsgálatának lehetőségeit [18]. Osteoporosisban szenvedő betegek panoráma felvételeken megfigyelhető radiomorphometriai és vizuális indexeinek vizsgálatával kapcsolatban azonban hiányoznak a hazai adatok.

Jelen vizsgálatunk célja az volt, hogy elemezzük a mandibula corticalis és panoráma felvételi osteoporosis-indexeinek, valamint az angulus szög értékének a reprodukálhatóságát panoráma röntgenfelvételeken. Továbbá, hazai populációban kívántunk adatokat nyerni az indexek számszerü értékéről, valamint diagnosztikai felhasználhatóságáról.

\section{Betegek és módszerek}

Egy előző tudományos munkánkhoz a Debreceni Egyetem Klinikai Központ (DE KK), Szülészeti és Nőgyógyászati Klinika Osteoporosis centrumában megvizsgált és diagnosztizált csontritkulásos betegek között fogorvosi szűrővizsgálatot szerveztünk [26]. A vizsgálat során - ha a klinikai eset indokolta - panoráma felvételt is készítettünk. A felvételeket a DE KK Fogorvostudományi Kar digitális röntgenarchívumába rögzítettük. Jelen vizsgálatban ezeket a röntgenfelvételeket elemeztük tovább. Ily módon a kísérleti csoport 50 diagnosztizált osteoporosisos, postmenopausa időszakában lévő nőből állt, akiknek életkora 55 és 81 év közé esett (átlagéletkor: 65,1 $\pm 5,9$ ). Őket még további két, egyenlő létszámú csoportra osztottuk életkoruk szerint, 65 év alattiakra $(60,4 \pm 3,0)$ és felettiekre $(70,1 \pm 3,8)$. A kontrollcsoportot 36 életkorban illesztett, osteoporosisra és egyéb anyagcsere betegségekre negatív anamnézisű nő alkotta. A kontrollcsoport tagjai 56 és 85 éves kor közé estek $(66,4 \pm 7,1)$. Öket is két csoportra osztottuk, 65 év alattiakra $(60,9 \pm 2,5)$ és 65 év felettiekre $(72,8 \pm 5,0)$.

A röntgenfelvételek PM 2002 CC Planmeca digitális panoráma készülékkel készültek. A felvételek készítése során a betegek anatómiai adottságainak megfelelő egyéni expozíciós paramétereket alkalmaztunk, amelyek átlagértékei a következők voltak: 72 kV csőfeszültség, 12 mAs csőáram és $18 \mathrm{mp}$ expozíciós idő.

A digitális felvételek elemzését 40 fogorvostan-hallgató és két egyetemi oktató végezte. A vizsgálatba negyed- és ötödéves hallgatókat vontunk be, mert ezen a területen ők már bizonyos elméleti tudással és klinikai gyakorlattal is rendelkeztek. Bevonásuk önkéntes alapon történt. A résztvevők számára a két oktató elméleti és gyakorlati képzést tartott, amelynek célja az osteoporosis panoráma felvételen azonosítható jeleinek ismertetése és a jelen vizsgálatban alkalmazott indexek rögzítési módja volt, ide értve a röntgenfelvételek elemzésére használt hardveres és szoftveres ismereteket is. A képelemzés menetéről rövid leírást készítettünk, amit minden részvevő az elemzés előtt megkapott. Minden panoráma felvételt négyen értékeltek, úgymint két hallgató és két oktató. A hallgatók nem kérhettek külső segítséget, és azt sem tudták, hogy vannak, akik ugyanazt a (kódolt) felvételt vizsgálják.

A mérésekhez a GIMP 2.6.12, szabad felhasználású képelemző programot használtuk, amely lehetővé tette a felvételeken a fényerő és a kontraszt beállítását, a szögmérést, nagyítást, illetve a távolságmérést is. Azért erre a szoftverre esett a választásunk, mert előzetes vizsgálatainkban megállapítottuk, hogy képmegjelenítési paraméterei megfelelnek a panoráma röntgenkészülék saját programjának. Továbbá a program könnyen kezelhető volt, és lehetővé tette az általunk tervezett vizsgálatok elvégzését.

A felvételeken a mandibula corticalis index ( $\mathrm{MCl}$ ) és panoráma felvételi index (PMI) értékeit mértünk. A méré- 
sek elkezdése előtt, adott nagyítási érték mellet, a kontrasztot és a fényerőt úgy állítottuk be, hogy minden releváns képlet láthatóvá váljon és tökéletesen körvonalazódjon.

A mandibula corticalis indexet $(\mathrm{MCl})$ a mandibula alsó corticalis lemezének radiológiai integritása alapján határoztuk meg, így $\mathrm{MCl} 1, \mathrm{MCl} 2$ és $\mathrm{MCl} 3$ értéket különítettünk el, az alábbiak szerint [16]:

MCI 1: a mandibula bázis alsó corticalisának felső széle folyamatos lefutású, a belső szerkezete homogénen radiopak

MCI 2: az alsó corticalis felső szélén folyamatosság-hiányok, behúzódások vannak, a belső szerkezete azonban homogénen radiopak

MCI 3: az alsó corticalis felső szélén folyamatosság-hiányok, behúzódások vannak, a belső szerkezete pedig szivacsos, üreges (1. ábra).

A mandibula panoráma felvételi indexének (PMI) meghatározásához távolságmérést végeztünk [21], amihez a képelemző szoftver pixelértékeit használtuk. A PMI egy arányszám, amelyet akkor kapunk meg, ha a corticalis réteg vastagságát elosztjuk a foramen mentale legmélyebb pontja és a mandibula bázis alsó széle közötti távolsággal (1. ábra). Jelen vizsgálatban a corticalis réteg vastagságát, a nagyobb precizitás érdekében úgy kalkuláltuk, hogy a foramen legmélyebb pontja és a mandibula alsó széle közötti távolságból kivontuk a foramen legmélyebb pontja és a corticalis lemez felső pontja közötti távolságot. A precizitást fokozta, hogy a mérés közben, miután a foramen legmélyebb pontját kijelöltük, arról a pontról már nem mozdítottuk el a kurzort. A mandibula alsó szélének referenciapontját egy érintő geometriai szerkesztésével jelöltük ki.

A mandibula angulus szögértékének mérését egy előző munkánkban közölt módszer adaptálásával végeztük el [34]. A nagyobb pontosság kedvéért, a szoftver beépített szögmérője segítségével, két szög méréséből számítottuk ki. Az egyik érték a mandibula ramusának a vízszintessel bezárt szöge ( $\alpha$ ), a másik pedig a mandibula bázisának a vízszintessel bezárt szöge ( $\beta)$. Ebből számítottuk ki a szöget (MA) a következőképpen: $M A=(180-\alpha)+\beta$.

$A z$ adatokat Microsoft Office Excel táblázatkezelőben rögzítettük, a PMI indexet egy algoritmussal számoltuk és összesítettük $\mathrm{MCl}$ adatokkal. Az értékek reprodukálhatóságára vonatkozóan adatainkat statisztikai vizsgálatoknak vetettük alá. SPSS program segítségével kétféle tesztet alkalmaztunk: független mintás t-próbát a PMI esetében, míg a corticalis indexnél a Pearson-féle $\chi^{2}$ teszt alkalmazása mellett döntöttünk - mivel ez az index csak háromféle diszkrét értékkel rendelkezik. Az adatokat a paraméterek értéke, valamint a mérést végző személyek csoportba tartozása alapján dolgoztuk fel. Az elemzéseket többféle csoportosítás szerint végeztük el, úgymint: a kísérleti csoport adatai, kontrollcsoport adatai, 65 év alattiak adatai, 65 év

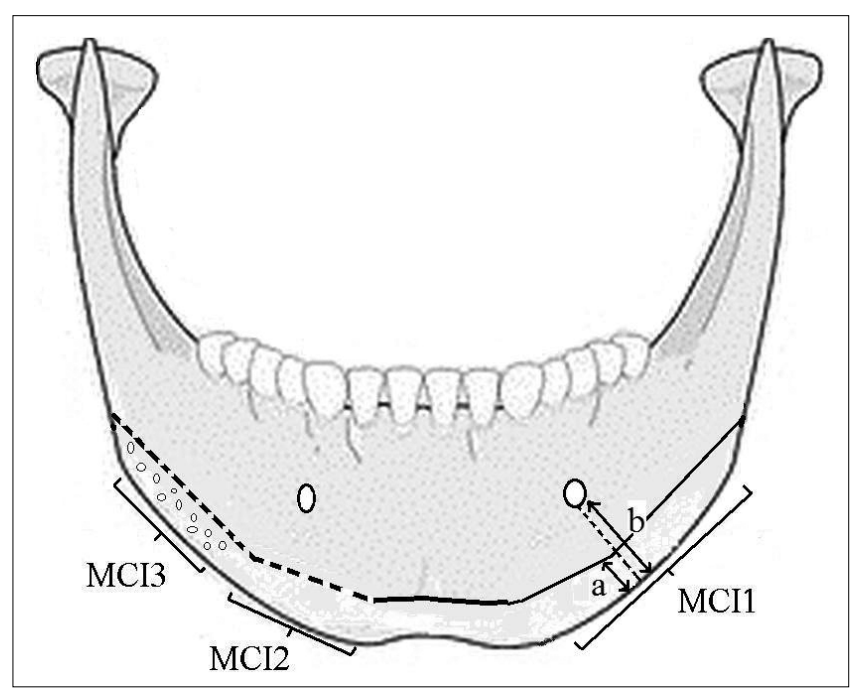

1. ábra: Hipotetikus ábra a mandibula corticalis $(\mathrm{MCl})$ és panoráma felvételi index (PMI) meghatározásának módjáról. Az MCI meghatározása az alsó corticalis lemez radiológiai integritása alapján történik.

A PMI egyenlő a corticalis lemez vastagsága

(a) elosztva a foramen mentale alsó szélének a mabdibula bázis peremétől mért távolsággal (b).

felettiek adatai, valamint az előbbiek kombinálása és végül minden adatra vonatkozó elemzések. A statisztikai próbákkal azt kívántuk tisztázni, hogy az osteoporosisra vonatkozó mérési eredmények függenek-e attól, hogy ki végezte el a mérést (vagyis reprodukálhatók-e a mérések)?

\section{Eredmények}

A mandibula corticalis index átlaga minden vizsgált személyre vonatkoztatva 1,56 $\pm 0,66$. A 65 év alatti csontritkulásos csoportban 1,52 $\pm 0,65$, a kontrollcsoportban pedig 1,32 \pm 0,47 index értékeket kaptunk (1. táblázat). Ezek az értékek 65 év felett 1,61 $\pm 0,65$ és 1,86 $\pm 0,77$ voltak. Független mintás t-próbával 65 év alatt szignifikáns eltérést találtunk a teszt és a kontrollcsoport adatai között, a két tesztcsoport között viszont nem ( $p<$ $0,05)$. A két kontrollcsoport adatai között szintén szignifikáns eltérés mutatkozott.

A panoráma felvételi index (PMI) értékeinek átlaga minden résztvevőre számítva $0,31 \pm 0,09$ volt. Az osteoporosisos csoportban 65 év alatt 0,32 \pm 0.08 , a 65 év felettiben pedig 0,29 $\pm 0,09$ voltak az átlagértékek (1. táblázat). A kontrollcsoport ugyanezen értékei 0,33 $\pm 0,09$ és $0,30 \pm 0,10$ voltak. A PMI értékekben a 65 év alatti és feletti teszt-csoportok között találtunk szignifikáns eltérést $(p<0,05)$.

$A z$ angulus mandibulae szögértékei a kísérleti csoportban 65 év alatt 126,53 \pm 6,89, 65 év felett 125,08 \pm 9,22 voltak (1. táblázat). Ezekre az értékekre a kontrollcsoportokban 125,40 \pm 6,72 és 126,21 \pm 6,75 szögeket kaptunk. A csoportátlagok között szignifikáns eltérést nem sikerült kimutatni. 
1. táblázat

A mandibula corticalis (MCl)

panoráma felvételi (PMI) indexek

és az angulus mandibulae szögértékének átlaga, csoportonkénti megoszlásban.

\begin{tabular}{|l|c|c|c|}
\hline Vizsgáltak köre & $\begin{array}{c}\mathrm{MCl} \\
(\text { átlag } \pm \mathrm{SD})\end{array}$ & $\begin{array}{c}\mathrm{PMI} \\
(\text { átlag } \pm \mathrm{SD})\end{array}$ & $\begin{array}{c}\text { Gon } \\
\text { (átlag } \pm \mathrm{SD})\end{array}$ \\
\hline teszt $>65$ év & $1,52 \pm 0,65$ & $0,32 \pm 0,08$ & $126,53 \pm 6,89$ \\
\hline teszt <65 év & $1,61 \pm 0,65$ & $0,29 \pm 0,09$ & $125,08 \pm 9,22$ \\
\hline kontroll $>65$ év & $1,32 \pm 0,47$ & $0,33 \pm 0,09$ & $125,40 \pm 6,72$ \\
\hline kontroll <65 év & $1,86 \pm 0,77$ & $0,30 \pm 0,10$ & $126,21 \pm 6,75$ \\
\hline
\end{tabular}

2. táblázat

A mandibula corticalis indexének reprodukálhatósága Pearson-féle $\chi^{2}$ (Khí-négyzet) teszt alapján.

$A$ " $\chi^{2}$ mutató" oszlopban a maximális és zárójelben a tényleges értékek vannak.

A csillaggal jelölt értékek szignifikáns eltérést mutatnak (szignifikancia határ: 0,05),

ahol az elemzó személye befolyással bír a kapott értékre.

\begin{tabular}{|c|c|c|}
\hline Vizsgáltak köre & $\chi^{2}$ mutató & Szignifikancia \\
\hline összes & $437 \quad(4,653)$ & 0,098 \\
\hline kontroll & $211 \quad(0,109)$ & 0,947 \\
\hline teszt & $226 \quad(7,566)$ & $0,023^{*}$ \\
\hline$<65$ év & $239(10,533)$ & $0,005^{*}$ \\
\hline$>65$ év & $198 \quad(0,463)$ & 0,793 \\
\hline$<65$ év teszt & $110(10,920)$ & $0,004^{*}$ \\
\hline < 65 év kontroll & $110 \quad(0,545)$ & 0,461 \\
\hline$>65$ év teszt & $97 \quad(0,622)$ & 0,733 \\
\hline$>65$ év kontroll & $101 \quad(0,139)$ & 0,933 \\
\hline
\end{tabular}

Az oktatók és a hallgatók által regisztrált indexek reprodukálhatóságára vonatkozó, több szempont figyelembevételével elvégzett Pearson féle $\chi^{2}$ és a független mintás t-próba eredményei a corticalis index vonatkozásában mutattak eltérést a hallgatók és az oktatók között (2. táblázat). Ezzel a statisztikai próbával azt elemeztük, hogy a vizsgálók milyen arányban leletezték megegyezően vagy eltérően a mandibula corticalisára vonatkozó $\mathrm{MCl} 1, \mathrm{MCl} 2$ és $\mathrm{MCl} 3$ értékeket. Az eltérések az összesített tesztcsoportra, a 65 év alattiakra és a 65 év alatti tesztcsoportra feldolgozott adatokban nyilvánultak meg. A két oktató eredményei között viszont nem találtunk szignifikáns eltérést, statisztikailag tehát ugyanazokat az adatokat regisztrálták a vizsgált paraméterek esetén.

\section{Megbeszélés}

Az osteoporosis világszerte komoly népegészségügyi és nemzetgazdasági probléma, a kórkép gyakorisága, az ellátás költségei és a szövődmények súlyossága miatt $[28,36]$. A születéskor várható élettartam megnövekedése nyilvánvalóan tovább emeli az ellátórendszerre háruló kihívásokat, hiszen a nők életük kb. egyharma- dát élik át védőhatású ösztrogén nélkül. 2010-es adatok szerint Magyarországon kb. 550 ezer osteoporosisos beteg él (T-score $\leq-2.5 \mathrm{SD}$ ), ami kb. 100 ezer osteoporoticus törést eredményez évente [31, 19]. Az OEP adatbázisa alapján a 2003-ban csípőtáji törést elszenvedett nők csak 5,8\%-a, a férfiaknak pedig 1,8\%-a ment el az előző naptári évben osteoporosis szürővizsgálatra [6], ami egyrészt a szürővizsgálatok alacsony hatékonyságára, másrészt a betegek hiányos motiváltságára utal. Az osteoporosissal összefüggő csípőtáji törések magas mortalitásuk és az életminőségre gyakorolt kedvezőtlen utóhatásuk miatt kiemelt fontossággal bírnak. Hazánkban mintegy 12 ezer fő szenved el ilyen sérülést évente, akiknek $31 \%$-a halálozik el egy éven belül [29].

A fenti adatok, továbbá az a tény, hogy korai felismeréssel az osteoporosis jól kezelhető és a szövődményei is megelőzhetők, a szürővizsgálatok jelentősége mellett szólnak. Hazánkban jelenleg a kötelező egészségbiztosítás keretében igénybe vehető szűrővizsgálatok között az osteoporosis szürése nem szerepel [1]. A rutinszerű csontritkulás szúréseket azonban a WHO sem tartja indokoltnak, mivel hiányoznak azok a nagy populáción végzett, jól kontrollált elemzések, amelyek alátámasztanák pozitív hatásukat a kórkép terápiájára és a kezelt betegek életminőségére [28]. Egy Európai Unió-s szintű osteoporosis-jelentés hazánkra vonatkozóan kiemeli, hogy bár 2001 és 2011 között nőtt a terápiás beavatkozások száma, azonban egy 50 év körüli és afeletti, osteoporosisra fogékony csoportban nemkívánatos visszaesés volt tapasztalható [31]. A hazai gyakorlat követi a nemzetközi irányelveket, amelyek szerint országos szürés helyett a beteg kora, neme és anamnézise által indokolt esetekben végeznek diagnosztikus vizsgálatot $[23,30]$. A családorvosi gyakorlatban ez a 65 év feletti menopauza utáni nők, a 65 év alatti, de fokozott kockázatnak kitettek, a rizikócsoportba tartozó nők és férfiak, illetve a típusos osteoporosisos törésen átesett páciensek szűrővizsgálatra utalását jelentheti. Jelen munkánkban ennek megfelelően osztottuk 65 év alattiakra és felettiekre a vizsgálatban résztvevőket.

Abból következően, hogy az átfogó lakossági szűrővizsgálatok jelenleg nem megoldhatók, a pácienseknek nincs betegségtudatuk, a panaszok jelentkezésekor viszont a beteg már későn kerül orvoshoz, az egyéb - közöttük a fogorvosi vonatkozású - diagnosztikai eljárások jelentősége felértékelődik. A fogorvosi szakirodalomban számos közlemény tárgyalja a csontritkulás következményeként kialakuló orofaciális elváltozásokat, valamint az azzal összefüggő csontszerkezeti változásokat $[4,33]$. Ez utóbbi csoportba tartoznak a mandibula radiomorfometriai és vizuális indexeinek az osteoporosis diagnosztikájában és prevenciójában játszott szerepét tanulmányozó közlemények [21, 32].

A mandibula osteoporosis-indexeinek jelentőségét növeli, hogy hazánkban a kötelező egészségbiztosítás keretében térítésmentesen igénybe vehető rendszeres fogorvosi szűrővizsgálat lehetősége adott, amit sokan 
ki is használnak. Ilyenkor fogorvos-szakmai indikációk alapján gyakorta készítünk röntgenfelvételeket, amelyeken megfelelő ismeretek birtokában egyszerűen azonosíthatjuk a csontritkulásra utaló jeleket. A fogorvosi radiológiai felvételek közül erre a célra elsősorban a panoráma röntgenfelvétel alkalmas, de újabban a kúpsugaras komputertomográfia (CB-CT, és ezzel kapcsolatban a mandibula CT indexek) jelentőségére is felhívják a figyelmet [17]. Taguchi egészségügyi és költséghatékonysági okokkal is alátámasztja a panoráma indexek használatát, kiemelve, hogy a felvételek projekciós paramétereinek jó megismételhetősége lehetőséget biztosít az állapot követésére is [32]. Egy 2008-as európai uniós felmérés szerint hazánkban a DEXA (dual energy x-ray absorptiometry) osteoporosis szürővizsgálat költsége 25 euro [28]. Hangsúlyoznunk kell azonban, hogy a panoráma felvételeket a fogorvosi gyakorlatban az osteoporosistól eltérő indikációval készítjük, így az nem is lehet célunk, hogy szürővizsgálati jelleggel használjuk. Ettől függetlenül, ha indokolt esetben a beteget szakrendelésre utaljuk, abból az egészségügyi hasznosság mellett gazdasági nyereség is származhat.

Horner és mtsai akkor tartják indokoltnak az osteoporosis szürővizsgálatra utalást, ha a corticalis index, $\mathrm{MCl}=3$ vagy a mentalis index értéke kisebb, mint 0,3, illetve a PMI < 0,3 [12]. Eredményeinkből arra következtetünk, hogy ez a $\mathrm{PMI}<0,3$ indexhatár esetünkben nem elég specifikus (túl megengedő), mivel ez alapján a 65 év alatti kontroll csoportból a résztvevők 35\%-át, a felettiből pedig az 59\%-át kellene osteoporosis szakrendelésre utalni. A két arányérték jelentős eltéréséből arra következtethetünk, hogy a páciensek korát is figyelembe kell vennünk, ha egy kellően szenzitív és specifikus hazai index határértéket szeretnénk megállapítani. Ugyanezen, 0,3\%-os PMI határérték alapján a 65 év alatti osteoporosisos csoport 68\%-a kimaradna a szűrésre utaltak közül, mivel az álnegatívok kategóriájába esne. Amennyiben a szürésre utalás kritériumának a $\mathrm{PMI}<0,3$ vagy az $\mathrm{MCl}=3$ feltétel bármelyikének teljesülését tekintjük, az álnegatívok aránya ebben a csoportban nem csökkenne, mivel az $\mathrm{MCl}$ index nem növelte a PMI indexhatár szenzitivitását. A 65 év feletti osteoporosisos csoportban a szürésre utalandók, $\mathrm{MCl}$ szürővel és nélküle is, $30 \%$-nak bizonyultak. Amikor azt vizsgáltuk, hogy a két index együttes alkalmazása, hogyan változtatta meg a kontroll csoportokban a tévesen pozitív eredményeket (35\% és 59\%), megállapítottuk, hogy nincs számottevő emelkedés, vagyis a feleslegesen szürésre küldött páciensek aránya nem nő lényegesen. A két teszt együttes alkalmazása tehát, ebben az esetben, nem okozott érdemi szenzitivitás növekedést. Erre vonatkozó konkrét adataink szerint, 65 év alatt a PMI plusz $\mathrm{MCl}$ indexek együttes alkalmazása nem változtatta meg a 35\%-os álpozitív arányt, a 65 év feletti kontroll csoportban viszont csak 65\%-ra emelte. Ezek az adatok azonban aránytalanul magasnak tûnnek a hazai, korcsoportra vonatkozó, 7-10\%-os osteoporosis gyakorisághoz képest. Meg kell azonban jegyeznünk, hogy a kontroll csoportban csak akkor tudnánk teljesen megbízható álpozitív adatokat közölni, ha a kontroll pácienseken is elvégeztük volna a DEXA vizsgálatot.

A vizsgált indexek értékeit a csoportok között öszszehasonlítva megállapíthatjuk, hogy 65 éves kor felett a corticalis index értékei magasabbak, ami arra enged következtetni, hogy a kor előrehaladtával a csontlebontódás felé mutató (II. típusú primer osteoporosisos) folyamatok felerősödnek a postmenopausalis osteoporosis jelenlététől függetlenül is. Hasonlóan, a PMI index értékei a 65 év alatti osteoporosisos személyeknél megközelítik a 65 év feletti kontroll csoport értékeket.

Dutra és mtsai szerint a mandibula osteoporosisban alaki változásokon meg keresztül, ami megmutatkozik a panoráma felvételen mérhető szögértékeken is [9]. Jelen vizsgálatban a mandibula angulus szögértékét mértük, ami nem mutatott statisztikailag értékelhető különbséget a csoportok között. Meg kell jegyeznünk azonban, hogy a hivatkozott szerzők nálunk komplexebb vizsgálatot végeztek (más szögeket is bevontak munkájukba), amelyeket mi nem tudtunk kivitelezni.

Vizsgálatunk legfontosabb klinikai vonatkozású következtetése, hogy a fogorvos, alapszintű gyakorlat és kellő felkészültség birtokában, képes lehet a panoráma felvételi osteoporosis indexek precíz meghatározására. Ez egybecseng más szerzők közölt adataival [2]. A PMIindex az elemző szakmai gyakorlatától függetlenül reprodukálható, a $\mathrm{MCl}$-index esetében azonban, adataink szerint, nagyobb hangsúlyt kell fektetni a képzésre. Különös nyomatékot ad eredményeinknek, hogy azokban a csoportokban (az összesített tesztcsoportban, 65 év alattiaknál és a 65 év alatti tesztcsoportban) kaptunk eltérést az oktatók és a hallgatók mérései között, ahol az osteoporosis jelei intenzíven megnyilvánulnak. Kézenfekvő magyarázat, hogy a corticalis lemezen megjelenő elváltozások megítéléséhez nagyobb gyakorlat szükséges, mint az alapvetően távolság és szögmérést igénylő másik két vizsgálathoz. Jowitt és mtsai jelen tanulmányunkhoz hasonló vizsgálatot végeztek és megállapították, hogy az elemzők precizitása fokozható a gyakorlati tapasztalat növelésével [13]. Minél alaposabb tréninget tartottak ugyanis a vizsgálatok előtt, az eredmények annál pontosabbak voltak. Nakamoto és mtsai is azt hangsúlyozzák, hogy a nagyobb szakmai gyakorlattal rendelkező fogorvosok pontosabban azonosítják az osteoporosis jeleit a panoráma felvételeken [24]. Alkurt és mtsai, hozzánk hasonlóan, arra a megállapításra jutottak, hogy a panoráma indexek jól reprodukálhatók. Jelentős különbség azonban, hogy míg mi egyetemi oktatókat és klinikai gyakorlatban jártas fogorvostanhallgatókat, ők fogorvos- és maxillo-faciális radiológusokat kértek fel a mérések elvégzésére [2]. Güngör és mtsai is azt állapították meg, hogy reprodukálhatók az eredmények, de az előzetes gyakorlat jelentékenyen befolyásolja a kapott értékeket [11]. Ledgerton és mtsai az előzőhöz hasonló kísérletet végeztek 2 vizsgálóval, akik kétszer elemezték ugyanazokat a felvételeket, de 
ők nem találtak jelentős különbséget közöttük, a kapott értékek jó egyezést mutattak, mind a vizsgálók között, mind pedig egy vizsgáló ismételt méréseit tekintve [21].

Különböző földrajzi régiókból, feltehetően etnikai, gazdasági, szociális, kulturális okok miatt eltérő panoráma felvételi index átlagértékeket közölnek [32, 15]. Ezért is tartottuk fontosnak jelen vizsgálatok végzését a hazai populációra vonatkozóan. A vizsgálatban résztvevő személyek kor szerinti megosztását azért tartottuk indokoltnak, mert mind az osteoporosis diagnosztikájában, mind terápiájában - és ennek megfelelően a vonatkozó szakirodalomban - a kor alapján is megkülönböztetnek rizikócsoportokat. A magyarországi szakmai protokoll az alábbi állásfoglalást tartalmazza az oszteodenzitometria elvégzésére vonatkozóan: „A denzitometria fontosabb indikációi: 65 év feletti életkor, a porosisos törés rizikófaktorai, hypogonadismus, szteroidkezelés, röntgennel felismert csigolyadeformitás, antiporotikus gyógykezelés indítása előtt minden esetben" [3]. Emellett, előzetes vizsgálataink alapján, $\mathrm{mi}$ is arra a megállapításra jutottunk, hogy 65 év felett megnő a panoráma röntgenfelvételen detektálható elváltozások száma.

A fogorvosi gyakorlatban gyakran készítünk a diagnózist és a kezelési tervet segítő panoráma felvételeket. Erre elsősorban fogpótlástani, parodontológiai és szájsebészeti beavatkozások előtt kerül sor. Az osteoporosisra veszélyeztetett csoportokban a fenti okok miatt különösen gyakorta kerülhet sor ilyen vizsgálatokra. Irodalmi adatok alapján ezek a felvételek, eltérő indikációjuktól függetlenül, segítséget jelenthetnek a csontritkulás diagnosztikájában. Egy teszt azonban csak akkor bizonyul hasznosnak, ha kielégítő a vizsgálóktól független reprodukálhatósága. Eredményeink alapján kijelenthetjük, hogy a corticalis és a panoráma felvételi indexek értékei reprodukálhatók, de a corticalis index esetében az elemző gyakorlottságának szignifikáns hatása van az eredményre.

Azt is elmondhatjuk, hogy a nemzetközi szakirodalomban az osteoporosis-szűrésre utalás céljából ajánlott panoráma-index határértékek az általunk vizsgált populációban nem bizonyultak hatékonynak. Ezért további vizsgálatokra lenne szükség populáció specifikus indexek kidolgozása céljából. Hangsúlyozni kívánjuk továbbá, hogy jelen munkánkban nem a panoráma indexek osteoporosis diagnosztikai érvényességét vizsgáltuk, hanem annak egy fontos előfeltételét, a reprodukálhatóságot.

Klinikai vonatkozású következtetésünk, hogy a fogorvos, megfelelő elméleti ismeretek birtokában, a szakma szabályai szerint készült panoráma röntgenfelvételen azonosíthatja az osteoporosis jeleit, amelyekkel kapcsolatban konzultációt folytathat a megfelelő általános orvos kollégával. Ennek az lehet az eredménye, hogy a páciens, még mielőtt a kórkép panaszt, súlyosabb esetben csonttörést okozna, osteoporosis szakrendelésre kerülhet. Az időben megkezdett kezelés pedig számottevően javíthatná betegeink elégedettségét és életminőségét.

\section{Irodalom}

1. 51/1997. (XII. 18.) NM rendelet a kötelező egészségbiztosítás keretében igénybe vehető, betegségek megelőzését és korai felismerését szolgáló egészségügyi szolgáltatásokról és a szűrővizsgálatok igazolásáról. http://njt.hu/cgi_bin/njt_doc.cgi?docid= 30023.289049 (Utolsó elérés: 2016.02.14.)

2. Alkurt MT, Peker I, Sanal O: Assessment of repeatability and reproducibility of mental and panoramic mandibular indices on digital panoramic images. Int Dent J 2007: 433-438.

3. Apor P, BaJnokı L: Anyagcsere-Endokrinológiai útmutató 2008 , Medition, Budapest, 2008: 9-54.

4. Bandela V, Munagapati B, Karnati RK, Venkata GR, Nidudhur SR: Osteoporosis: Its Prosthodontic Considerations - A Review. J Clin Diagn Res 2015: 1-4.

5. Benson BW, Prihoda TJ, Glass BJ: Variations in adult cortical bone mass as measured by a panoramic mandibular index. Oral Surg Oral Med Oral Pathol Oral Radiol Endod 1991: 349-356.

6. BonCz I, PÉnTteK M, Falusı Zs és mtsai.: Az osteoporosis hálózat igénybevételi mutatóinak elemzése OEP-adatok révén. $C a$ és Csont 2006: 12-13.

7. Calciolari E, Donos N, Park JC, Petrie A, Mardas N: Panoramic measures for oral bone mass in detecting osteoporosis: a systematic review and meta-analysis. J Dent Res 2015(suppl): 17-27.

8. Drozdzowska B, Pluskiewicz W: Longitudinal changes in mandibular bone mineral density compared with hip bone mineral density and quantitative ultrasound at calcaneus and hand phalanges. Br J Radiol 2002: 743-747.

9. Dutra V, Devlin H, Susin C, Yang J, Horner K, Fernandes ar: Mandibular morphological changes in low bone mass edentulous females: evaluation of panoramic radiographs. Oral Surg Oral Med Oral Pathol Oral Radiol Endod 2006: 663-668.

10. Groen JJ, Menczel J, Shapiro S: Chronic destructive periodontal disease in patients with presenile osteoporosis. J Periodontol 1968: 19-23.

11. GÜNGÖR K, AKARSLAN Z: The precision of the panoramic mandibular index. Dentomaxillofac Radiol 2006: 442-446.

12. Horner K, DeVlin H, Harvey L: Detecting patients with low skeletal bone mass. J Dent 2002: 171-175.

13. Jowitt N, MacFarlane T, Devin H: The reproducibility of the mandibular cortical index. Dentomaxillofac Radiol 1999: 141-144.

14. KLemettI E; Kolmakov S: Morphology of the mandibular cortex on panoramic radiographs as an indicator of bone quality. Dentomaxillofac Radiol 1997: 22-25.

15. Klemetti E, Kolmakov S, Heiskanen P, Vainio P, Lassila V: Panoramic mandibular index and bone mineral densities in postmenopausal women. Oral Surg Oral Med Oral Pathol Oral Radiol Endod 1993: 774-779.

16. Klemetti E, Kolmakov S, Kroger H: Pantomography in the assessment of the osteoporosis risk group. Scand J Dent Res 1994: 68-72.

17. $\mathrm{KoH} \mathrm{KJ}$, KIM KA: Utility of the computed tomography indices on cone beam computed tomography images in the diagnosis of osteoporosis in women. Imaging Sci Dent 2011: 101-106.

18. KoppánY $F$, JoÓb-FAnCSAlY A, SZABo G: A csontsürüség meghatározásának lehetőségei a maxillofaciális régióban: irodalmi áttekintés. Fogorv Szle 2007: 77-81.

19. LaKatos P: Az osteoporosis gyógyszeres kezelése. Orvosi Hetilap 2011: 1320-1326.

20. LaKATOS $P$, TAKÁcs I: A csontanyagcsere betegségei. Semmelweis, Budapest, 2012: 103-119.

21. Ledgerton D, Horner K, Devlin H, Worthington H: Panoramic mandibular index as a radiomorphometric tool: an assessment of precision. Dentomaxillofac Radiol 1997: 95-100.

22. MohácsI R, BIRINYI L, Pataky L, Angyal J: Age related osteoporotic and spondylotic changes in panoramic radiographs. 13th Congress of EADMFR. Lipcse, Németország, 2012. 06. 13-16. http://eadmfr2012.hs.evermind.de/fileadmin/contents/images/programm/program_eadmfr2012.pdf (Utolsó elérés: 2016.02.14.) 
23. Mulligan R, Sobel S: Osteoporosis: Diagnostic testing, interpretation, and correlations with oral health-implications for dentistry. Dent Clin North Am 2005: 463-484.

24. Nagi R, Yashoda Devi BK, Rakesh N, Reddy SS, Santana S, Shetty N: Relationship between femur bone mineral density, body mass index and dental panoramic mandibular cortical width in diagnosis of elderly postmenopausal women with osteoporosis. J Clin Diagn Res 2014: 36-40.

25. NAGY É: A csontritkulásos betegek szűrésének és gondozásának jelentősége a háziorvosi gyakorlatban. Hippocrates 2001: 36-41.

26. Nakamoto, T, Taguch A, OHtsuka M: Dental panoramic radiograph as a tool to detect postmenopausal women with low bone mineral density: untrained general dental practitioners' diagnostic performance. Osteoporos Int 2003: 659-664.

27. Nilas L, Nörglíd H, Pödenphant J, Gotrredsen A, Christiansen C: Bone composition in the distal forearm. Scand J Clin Lab Invest 1987: 41-46.

28. Osteoporosis in the European Community: Action Plan. A Report of the European Union Osteoporosis Consultation Panel. 2003. http://ec.europa.eu/health/ph_projects/2002/promotion/fp_promotion_2002_a1_04_en.pdf (Utolsó elérés: 2016.02.14.)
29. Somogyı P, KRIcsfalusy M, GaÁl J, Cserhátı P: Csípőtáji törések jelentősége a magyarországi adatok tükrében. Osteologiai Közlemények 2010: 67-72.

30. Somogy P: Osteoporosis szűrés lehetőségei és tapasztalatai Magyarországon. Népegészségügy 2011: 345-350.

31. Svedbom A, Hernlund E, Ivergard M, Compston J, Cooper C, StenMARK J, et al.: Osteoporosis in the European Union: a compendium of country-specific reports. Arch Osteoporos 2013: 8: 137.

32. TAGUCHI A: Triage screening for osteoporosis in dental clinics using panoramic radiographs. Oral Dis 2010: 316-327.

33. Taguchi A, Tanimoto K, Sue Y: Oral signs as indicators of possible osteoporosis in elderly women. Oral Surg Oral Med Oral Pathol Oral Radiol Endod 1995: 612-616.

34. То́тH ZsO, Udvar O, ANGyal J: Kormeghatározás panoráma röntgenfelvételek alapján. Fogorv Szle 2014: 93-98.

35. White SC, Rudolph DJ: Alterations of the trabecular pattern of the jaws in patients with osteoporosis. Oral Surg Oral Med Oral Pathol Oral Radiol Endod 1999: 628-635.

36. WHO Scientific Group: Prevention and Management of Osteoporosis. WHO Technical Report Series No 921. Geneva: WHO Press 2003. http://apps.who.int/iris/bitstream/10665/42841/1/WHO _TRS_921.pdf (Utolsó elérés: 2016.02.14.)

\section{Fehér M, Kukı A, Mohácsı R, BIRINyı L, Angyal J \\ Precision evaluation of panoramic morphometric index measurements performed by experienced clinicians and dental students}

Osteoporosis is a chronic degenerative disease of bones in which the primary type of it affects generally women after postmenopause. According to the literature the panoramic indices are valuable morphometric and visual tools to detect the disorder in an early and asymptomatic stage. The goals of study were to evaluate the reproducibility of mandibular cortical and panoramic indices and to assess population-specific index parameters. Panoramic radiographs of 50 osteoporotic $($ age $=65,1 \pm 5,9)$ and 36 control (age $=66,4 \pm 7,1)$ women were evaluated for the cortical $(\mathrm{MCl})$ and panoramic (PMI) indices by 2 experienced clinicians and 40 dental students with basic clinical experiences. Statistical analysis of data was preformed using SPSS software. The result of $\mathrm{MCl}$ and PMI indexes demonstrated high interobserver agreement between the two clinicians but in $\mathrm{MCl}$ data, recorded by the clinicians and students, showed statistically significant differences. On the other hand the mean and threshold values of the indices proved to be different from what we had expected from other surveys. Although the panoramic images are taken for specific dental indications that would improve the screening efficiency of osteoporosis when the clinician recognizes the signs of it on the radiographs.

Key words: panoramic radiography, osteoporosis, cortical index, mandibular index, reproducibility 